\title{
Growth and Productivity of Sugarcane Cultivated in Soils Submitted to Chiseling in the Planting Row and in Total Area
}

\author{
Nilvan Carvalho Melo ${ }^{1}$, Carolina Fernandes ${ }^{1}$, Edimar Rodrigues Soares ${ }^{1} \&$ Edson Luiz Mendes Coutinho ${ }^{1}$ \\ ${ }^{1}$ Faculdade de Ciências Agrárias e Veterinárias, Universidade Estadual Paulista, Jaboticabal, SP, Brazil \\ Correspondence: Nilvan Carvalho Melo, Faculdade de Ciências Agrárias e Veterinárias, Universidade Estadual \\ Paulista, Via de Acesso Prof. Paulo Donato Castellane s/n, 14884-900, Jaboticabal, SP, Brazil. Tel: \\ 55-96-991-463-708. E-mail: nilvan.melo@ifap.edu.br
}

Received: September 23, 2018

Accepted: November 3, $2018 \quad$ Online Published: December 15, 2018

doi:10.5539/jas.v11n1p515

URL: https://doi.org/10.5539/jas.v11n1p515

The research is financed by São Paulo Research Foundation (FAPESP), process $n^{\circ}$. 2014/14490-2.

\begin{abstract}
Soil tillage carried out in total area in sugarcane field reform causes changes in soil structure, affecting root system development due to the use of agricultural machinery from planting to harvesting. Thus, we assessed the growth and stalk productivity of sugarcane cultivated in an Oxisol and Ultisol submitted to chiseling in the planting row and in total area. The experiment was conducted in two agricultural areas in a large paired-plot design. Treatments consisted of two areas submitted to chiseling in the planting row (CPR) and chiseling in total area (CTA) in an Oxisol and Ultisol. The variables number of tillers, number of green and dead leaves per plant, leaf area, leaf area index, plant height, and total dry matter were measured during six assessments over the crop cycle sugarcane planting with the variety CTC 14 in the Oxisol and with the variety CTC 4 in the Ultisol. In addition, stalk productivity was assessed after harvesting. The assessments were performed at 1071, 1705, 2388, 3600,4593 , and 5764 accumulated degree-days (ADD) in the Oxisol and at 821, 1519, 2294, 3570, 4562, and 5754 ADD in the Ultisol. Soil tillage with CPR can be replaced by CTA since growth and stalk productivity of sugarcane were similar regardless of the location of the chiseling operation.
\end{abstract}

Keywords: Saccharum sp., Ultisol, Oxisol, biometric analysis, minimum tillage

\section{Introduction}

Brazil is the world's largest sugarcane producer and may stand out even more in this scenario considering the increased demand for renewable fuels, its large extensions of arable lands, and its favorable edaphoclimatic conditions for sugarcane cultivation. In the 2016/2017 season, Brazilian sugarcane production was 657.2 million tons in a total area of 10.3 million hectares (CONAB, 2017).

In the period of sugarcane field reform, soil tillage for planting is usually carried out in total area in order to promote a better root system development. However, the use of this practice has contributed to altering soil structure due to the traffic of agricultural machinery and implements from soil tillage to harvesting, which can compromise growth and productivity of sugarcane crop (Cherubin et al., 2017). Thus, the use of soil management systems that provide a less soil mobilization, such as the minimum tillage carried out by chiseling, is necessary.

Chiseling is a soil tillage operation that consists of breaking compacted soil layers by means of the penetration of mechanical rods, promoting soil disaggregation usually up to $30 \mathrm{~cm}$ deep (Mialhe, 1974). The use of soil tillage operations with chiseling in the planting row has been adopted as an alternative in some sugarcane producing areas, although in an empirical way, promoting soil disaggregation in a smaller area, improving the quality of soil properties, and reducing production costs and use of fuel.

Sugarcane is planted in different types of soils, which vary according to the production environments. In the State of São Paulo, it is mainly cultivated in Oxisols and Ultisols, which represents approximately $47 \%$ of the planted area (Marin, 2017). Sandy soils present a lower water availability in the soil profile, but it does not mean that clayey or very clayey soils have the highest water availability since some soils have a high clay content and are very dry due to a strong micro-aggregation of clays (Prado, 2016). 
In addition to assessing soil attributes, it is important to assess plant growth. Growth variables are measured through biometric analyses, which are performed to quantify crop growth at different development stages and environmental conditions (Nassif et al., 2013). The assessment of sugarcane growth contributes to the identification of the stages in which the highest increases of the crop development occurs. The study of growth variables such as plant height, stalk diameter, tiller density, leaf structure, and sequential accumulation of dry matter assists in identifying the productive potential of varieties (Marafon, 2012). These growth variables show a positive relationship with productivity and, consequently, with the efficiency of its use for accumulating biomass and sucrose.

In this context, this study tests the hypothesis that the growth and productivity of sugarcane are similar when cultivated in soils with chiseling in the planting row and in total area. Therefore, the aim of this study was to assess the growth and stalk productivity of sugarcane cultivated in an Oxisol and Ultisol submitted to chiseling in the planting row and in total area.

\section{Method}

The experiment was conducted in two agricultural areas located in the State of São Paulo. In the first area, located in the municipality of Guariba and close to the geographical coordinates $21^{\circ} 24^{\prime} 25^{\prime \prime} \mathrm{S}$ and $48^{\circ} 12^{\prime} 12^{\prime \prime} \mathrm{W}$ and with an altitude $618 \mathrm{~m}$, the soil was classified as an Oxisol. In the second area, located in the municipality of Monte Alto and close to the geographical coordinates $21^{\circ} 15^{\prime} 23^{\prime \prime} \mathrm{S}$ and $48^{\circ} 25^{\prime} 52^{\prime \prime} \mathrm{W}$ and with an altitude of 735 $\mathrm{m}$, the soil was classified as an Ultisol. Both areas were cultivated with sugarcane under mechanized harvesting system for more than 20 years. In the year of experiment setup, no crop rotation was performed in the area, i.e. the management was sugarcane with sugarcane.

Regional climate, according to Köppen classification, is a mesothermal climate with a dry winter (Aw), annual average rainfall of 1,400 $\mathrm{mm}$ concentrated from November to February, and average temperature of the warmest and coldest months higher than 22 and $18{ }^{\circ} \mathrm{C}$. Precipitation, maximum, minimum and average daily temperature, and accumulated degree-days for the experimental period in the Oxisol and Ultisol areas are shown in Figure 1.
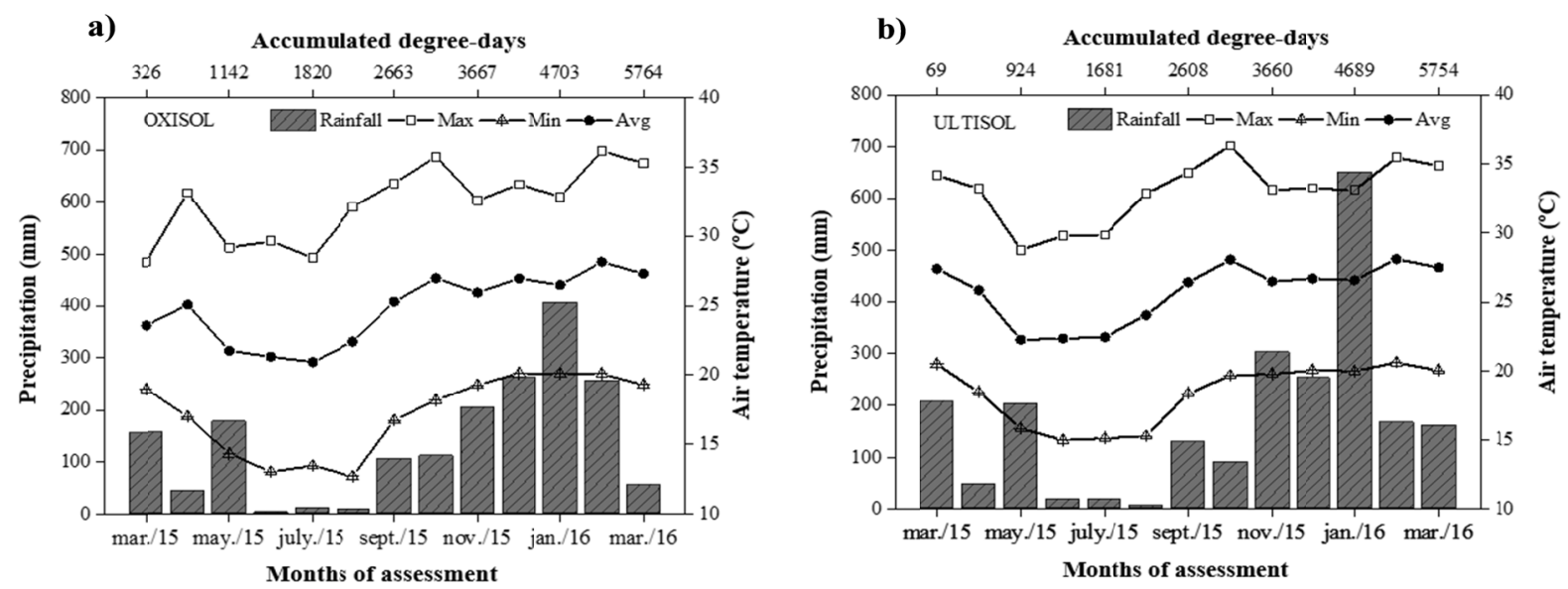

Figure 1. Precipitation, maximum, minimum and average daily temperature, and accumulated degree-days in the Oxisol (a) and Ultisol (b) areas in the period from March 2015 to March 2016

The characterization of soil chemical properties and texture were performed by means of samples collected in the $0.00-0.10$ and $0.10-0.20 \mathrm{~m}$ layers (Table 1). Particle size analysis was performed according to the methodology described by Claessen (1997) and soil chemical analysis was performed according to Raij et al. (2001), with the organic carbon content (OC) determined as described by Yeomans and Bremner (1988). 
Table 1. Means of soil chemical attributes and clay, sand, and silt contents in the $0.00-0.10$ and $0.10-0.20 \mathrm{~m}$ soil layers cultivated with sugarcane and submitted to chiseling in planting row (CPR) and in total area (CTA)

\begin{tabular}{|c|c|c|}
\hline & \multicolumn{2}{|c|}{ Soil layer $(\mathrm{m})$} \\
\hline & $0.00-0.10$ & $0.10-0.20$ \\
\hline \multicolumn{3}{|l|}{ Oxisol } \\
\hline $\mathrm{pH}$ in $\mathrm{H}_{2} \mathrm{O}$ & 5.7 & 5.5 \\
\hline $\mathrm{OC}\left(\mathrm{g} \mathrm{kg}^{-1}\right)$ & 30 & 26 \\
\hline $\mathrm{P}\left(\mathrm{mg} \mathrm{dm}^{-3}\right)$ & 37 & 31 \\
\hline $\mathrm{K}\left(\mathrm{cmol}_{\mathrm{c}} \mathrm{dm}^{-3}\right)$ & 0.16 & 0.14 \\
\hline $\mathrm{Ca}\left(\mathrm{cmol}_{\mathrm{c}} \mathrm{dm}^{-3}\right)$ & 3.9 & 3.5 \\
\hline $\mathrm{Mg}\left(\mathrm{cmol}_{\mathrm{c}} \mathrm{dm}^{-3}\right)$ & 1.7 & 1.4 \\
\hline $\mathrm{Al}\left(\mathrm{cmol}_{\mathrm{c}} \mathrm{dm}^{-3}\right)$ & 0 & 0 \\
\hline $\mathrm{H}+\mathrm{Al}\left(\mathrm{cmol}_{\mathrm{c}} \mathrm{dm}^{-3}\right)$ & 2.2 & 2.5 \\
\hline $\mathrm{SB}\left(\mathrm{cmol}_{\mathrm{c}} \mathrm{dm}^{-3}\right)$ & 5.8 & 5 \\
\hline $\operatorname{CEC}\left(\mathrm{cmol}_{\mathrm{c}} \mathrm{dm}^{-3}\right)$ & 8 & 7.5 \\
\hline V $(\%)$ & 72 & 67 \\
\hline Clay $\left(\mathrm{g} \mathrm{kg}^{-1}\right)$ & 548 & 572 \\
\hline Sand $\left(\mathrm{g} \mathrm{kg}^{-1}\right)$ & 321 & 321 \\
\hline Silt $\left(\mathrm{g} \mathrm{kg}^{-1}\right)$ & 131 & 107 \\
\hline \multicolumn{3}{|l|}{ Ultisol } \\
\hline $\mathrm{pH}$ in $\mathrm{H}_{2} \mathrm{O}$ & 5.6 & 5.5 \\
\hline $\mathrm{OC}\left(\mathrm{g} \mathrm{kg}^{-1}\right)$ & 8 & 6 \\
\hline $\mathrm{P}\left(\mathrm{mg} \mathrm{dm}^{-3}\right)$ & 16 & 14 \\
\hline $\mathrm{K}\left(\mathrm{cmol}_{\mathrm{c}} \mathrm{dm}^{-3}\right)$ & 0.14 & 0.13 \\
\hline $\mathrm{Ca}\left(\mathrm{cmol}_{\mathrm{c}} \mathrm{dm}^{-3}\right)$ & 2.3 & 2.1 \\
\hline $\mathrm{Mg}\left(\mathrm{cmol}_{\mathrm{c}} \mathrm{dm}^{-3}\right)$ & 0.8 & 0.7 \\
\hline $\mathrm{Al}\left(\mathrm{cmol}_{\mathrm{c}} \mathrm{dm}^{-3}\right)$ & 0 & 0 \\
\hline $\mathrm{H}+\mathrm{Al}\left(\mathrm{cmol}_{\mathrm{c}} \mathrm{dm}^{-3}\right)$ & 1.6 & 1.7 \\
\hline $\mathrm{SB}\left(\mathrm{cmol}_{\mathrm{c}} \mathrm{dm}^{-3}\right)$ & 3.3 & 2.9 \\
\hline $\operatorname{CEC}\left(\mathrm{cmol}_{\mathrm{c}} \mathrm{dm}^{-3}\right)$ & 4.9 & 4.6 \\
\hline V $(\%)$ & 66 & 63 \\
\hline Clay $\left(\mathrm{g} \mathrm{kg}^{-1}\right)$ & 136 & 163 \\
\hline Sand $\left(\mathrm{g} \mathrm{kg}^{-1}\right)$ & 794 & 799 \\
\hline Silt $\left(\mathrm{g} \mathrm{kg}^{-1}\right)$ & 70 & 38 \\
\hline
\end{tabular}

Note. $\mathrm{OC}=$ organic carbon, $\mathrm{P}=$ available phosphorus, $\mathrm{K}=$ potassium content, $\mathrm{Ca}=$ calcium content, $\mathrm{Mg}=$ magnesium content, $\mathrm{Al}=$ aluminum content, $\mathrm{H}+\mathrm{Al}=$ potential acidity, $\mathrm{SB}=$ sum of bases, $\mathrm{CEC}=$ cation exchange capacity, $\mathrm{V}=$ base saturation, Clay = clay content, $\mathrm{Sand}=$ sand content, Silt $=$ silt content.

Before the experiment setup, the sugarcane ratoon of the previous production cycle was eliminated. In the Oxisol, a mechanical ratoon eliminator was used in November 2014. In the Ultisol, the chemical elimination was carried out with $4 \mathrm{~L} \mathrm{ha}^{-1}$ of glyphosate in January 2015. In soils with a sandy texture in the first layers, as the Ultisol of the studied area, the chemical ratoon elimination is used since this is a soil more susceptible to water erosion when compared to the Oxisol.

Soil correction was performed in the Oxisol in December 2014 by applying $1.5 \mathrm{t} \mathrm{ha}^{-1}$ of limestone $(35 \% \mathrm{CaO}$, $15 \% \mathrm{MgO}$, and PRNT (Relative Total Neutralization Potential) $=81 \%$ ) to increase base saturation to $70 \%$ (Raij et al., 1997) and $1.0 \mathrm{t} \mathrm{ha}^{-1}$ of gypsum (17-20\% calcium). In the Ultisol, soil correction was carried out in January 2015 by applying $3.0 \mathrm{t} \mathrm{ha}^{-1}$ of limestone $(35 \% \mathrm{CaO}, 15 \% \mathrm{MgO}$, and PRNT $=81 \%)$ to increase base saturation to $70 \%$ and $1.0 \mathrm{tha}^{-1}$ of gypsum. Soil tillage by means of chiseling operations was performed on January 31,2015 , in the Oxisol and on February 17, 2015, in the Ultisol.

The experiment was conducted in a large paired-plot design (Perecin et al., 2015), allowing soil tillage operations and the mechanized sugarcane harvest. The experimental areas had 10 ha in the Oxisol and 9 ha in the Ultisol. Each area was composed of 20 plots, with 10 plots for each treatment with sizes of approximately 0.50 
ha for the Oxisol area and 0.45 ha for the Ultisol area.

Treatments consisted of chiseling in the planting row (CPR) and chiseling in total area (CTA). In CPR, chiseling was carried out in the direction of the planting rows using a chisel plow with two pairs of rods spaced at $1.5 \mathrm{~m}$ and working depth of $0.30 \mathrm{~m}$. The distance between each pair of rods is $0.50 \mathrm{~m}$, with two rollers. In CTA, chiseling was performed using a chisel plow with five rods spaced at $0.50 \mathrm{~m}$ and working depth of $0.30 \mathrm{~m}$, with two rollers.

The experimental plot in the Oxisol area measured $15 \mathrm{~m}$ wide and $280 \mathrm{~m}$ long, totaling $4,200 \mathrm{~m}^{2}$, with 10 sugarcane rows spaced at $1.5 \mathrm{~m}$. The useful area consisted of six central rows with $180 \mathrm{~m}$ each, totaling $1,620 \mathrm{~m}^{2}$. In the Ultisol area, the experimental plot measured $12 \mathrm{~m}$ wide and $220 \mathrm{~m}$ long, totaling 2,640 $\mathrm{m}^{2}$, with eight sugarcane rows spaced at $1.5 \mathrm{~m}$. The useful area consisted of four central rows with $120 \mathrm{~m}$ each, totaling $720 \mathrm{~m}^{2}$.

Sugarcane planting was carried out on March 7, 2015, with the variety CTC 14 in the Oxisol and on March 26, 2015, with the variety CTC 4 in the Ultisol.

According to the Sugarcane Technology Center (CTC, 2018), the variety CTC 4 has as characteristics a medium maturation (in the middle of the season), high tillering, younger erect leaves and the others arched, non-drying stalks even under flowering, excellent ratoon sprout, great closure, and high productivity, while CTC 14 has a late maturation, purplish and waxy palm heart, very green leaves, recommended for good and intermediate soils, high productivity, never flourishes, tolerant to drought, and erect.

In both areas, furrowing was performed up to a depth of $0.30 \mathrm{~m}$, with a spacing of $1.5 \mathrm{~m}$ between furrows. Fertilization consisted of the application of $45 \mathrm{~kg} \mathrm{ha}^{-1}$ of $\mathrm{N}, 125 \mathrm{~kg} \mathrm{ha}^{-1}$ of $\mathrm{P}_{2} \mathrm{O}_{5}$, and $125 \mathrm{~kg} \mathrm{ha}^{-1}$ of $\mathrm{K}_{2} \mathrm{O}$, in the planting furrow.

The assessed variables were the number of tillers, number of green and dead leaves per plant, leaf area, leaf area index, plant height, and total dry matter. Six assessments were carried out in the Oxisol and Ultisol with approximately two-month intervals. In the Oxisol, the assessments were performed at 79, 136, 191, 264, 324, and 390 days after planting (DAP), corresponding to 1071, 1705, 2388, 3600, 4593, and 5764 accumulated degree-days (ADD), respectively. In the Ultisol, the assessments were carried out at 58, 115, 170, 243, 304, and 371 DAP, which corresponds to $821,1519,2294,3570,4562$, and 5754 ADD, respectively. The sum of ADD during crop cycle was determined by the equation below, considering a base temperature of the sugarcane crop equal to $10^{\circ} \mathrm{C}$, as suggested by Smit and Singels (2006).

$$
\mathrm{ADD}=\sum_{\mathrm{i}=1}^{\mathrm{n}}\left(\mathrm{T}_{\mathrm{a}}-\mathrm{T}_{\mathrm{b}}\right)
$$

where, $\mathrm{T}_{\mathrm{a}}$ is the average daily air temperature $\left({ }^{\circ} \mathrm{C}\right)$ and $\mathrm{T}_{\mathrm{b}}$ is the base temperature of the crop $\left({ }^{\circ} \mathrm{C}\right)$.

The number of tillers was obtained in each assessment by counting the number of plants contained in two linear meters in the useful area of each plot. For the delimitation, care was taken not to choose lines with tillering failure, i.e. a distance higher than $50 \mathrm{~cm}$ without any plants.

For the variables number of green leaves, number of dead leaves, leaf area, leaf area index, and plant height, 20 plants in the two linear meters of the useful area of each plot were previously demarcated in order to obtain the measurement always on the same plants at each assessment.

The number of fully expanded green leaves capable of performing photosynthesis, i.e. fully expanded leaves counted from the leaf +1 (first leaf with visible ligule), was counted. A green leaf was considered that with more than $50 \%$ photosynthetically active area, i.e. an area with more than $50 \%$ green coloration. The remaining leaves were considered as dead leaves.

The leaf area (LA) was obtained from each tiller in the two linear meters by measuring the length and width with a ruler in the median portion of the leaf +3 (third leaf with visible ligule) and counting the number of green leaves, according to the equation of Hermann and Câmara (1999):

$$
\mathrm{LA}=\mathrm{L} \times \mathrm{W} \times 0.75(\mathrm{~N}+2)
$$

where, $\mathrm{L}$ is the length of the leaf $+3, \mathrm{~W}$ is the width of the median portion of the leaf +3 (third upper leaf fully expanded from the first leaf with visible ligule), 0.75 is the correction factor for the crop leaf area, $\mathrm{N}$ is the number of fully expanded leaves with at least $50 \%$ green area counted from the leaf +1 , and 2 is the weighting factor for leaves not yet fully expanded.

The leaf area index (LAI) was calculated using the expression:

$$
\text { LAI }\left(\mathrm{m}^{2} \mathrm{~m}^{-2}\right)=\mathrm{NT} \times \mathrm{LA} / \mathrm{S}
$$

where, NT is the number of tillers, LA is the leaf area per tiller $\left(\mathrm{m}^{2}\right)$, and $\mathrm{S}$ is the area used in the assessment 
$\left(\mathrm{m}^{2}\right)$.

Plant height was measured with a ruler from the distance from soil to the insertion of the leaf +1 . For the assessment of the total dry matter, five tillers were sampled in the useful area of each plot. These samples were separated into the tops, leaf, and stalk, being the tops consisting of the leaf rolls and the leaf +1 . In the leaf component (leaf + sheath), dry and green leaves were considered from the leaf +1 . After removing the pointers and green and dry leaves, the remainder was considered as the stalk.

After being separated, the tops, leaves, and stalks were weighed to determine the fresh matter. Subsequently, for determining the moisture, a sample of each component was taken and the fresh matter was determined immediately in the field. The material was taken to the laboratory and dried in a forced air circulation oven at $65^{\circ} \mathrm{C}$ until constant weight.

The mechanized sugarcane harvest was carried out on July 1, 2016, in the Oxisol and on July 18, 2016, in the Ultisol. Sugarcane was harvested in the ten plots of each treatment using a harvester Case model 8800 with 358 $\mathrm{hp}$, tracks, and automatic auto-tracker. This machine harvested and transferred the stalks to a composition of two transshipments with load cells to measure the harvested stalk mass in order to obtain the productivity $\left(\mathrm{t}^{\circ} \mathrm{ha}^{-1}\right)$. The yield of stalks per area was determined in the plots of each treatment, which allowed calculating the stalk productivity $\left(\mathrm{t} \mathrm{ha}^{-1}\right)$ in both areas.

The regression equations were calculated for each studied variable and fit as a function of accumulated degree-days in order to characterize sugarcane growth. A three-parameter logistic model was used to fit the curves and coefficients of determination using the software SigmaPlot $10^{\circledR}$.

$$
\mathrm{Y}=\frac{\mathrm{a}}{1+\mathrm{e}^{-\frac{\left(x-x_{0}\right)}{b}}}
$$

where, $\mathrm{a}$ is the asymptotic maximum, $\mathrm{b}$ is the growth rate, and $\mathrm{x}_{0}$ is the inflection point.

The minimum $\left(\mathrm{C}_{\min }\right)$ and maximum $\left(\mathrm{C}_{\max }\right)$ curvatures were calculated according to the method cited by Venegas et al. (1998), using the parameters of the nonlinear equations $C_{\min }=x_{0}-2 b$ and $C_{\max }=x_{0}+2 b$. The $C_{\min }$ indicates the moment in the accumulation curve in which the most expressive accumulations begin and the $\mathrm{C}_{\max }$ indicates the moment in which the accumulation of elements begins to stabilize.

The statistical analysis aimed to assess the effect of chiseling operations on sugarcane growth and was performed in a large and uniform plot design (Perecin et al., 2015). The means of stalk productivity were compared by the Tukey's test at $\mathrm{p}<0.05$ using the software SAS 9.2.

\section{Results and Discussion}

In the Oxisol, initially, the number of tillers presented a peak of 15 and 16 tillers when submitted to CTA and CPR, respectively, around 136 DAP, corresponding to 1705 ADD (Figure 2). However, this initial value decreased rapidly as tillers died from the second assessment, regardless of the treatment. In the Ultisol, the number of tillers presented a similar behavior, with maximum values of 22 tillers under CPR and 29 tillers when submitted to CTA at 170 DAP, which corresponds to approximately 2294 ADD (Figure 2). However, different amplitudes of tillering were observed between both treatments. In CPR, sugarcane tillering was lower from 1519 ADD (115 DAP) onwards when compared to CTA. However, for the Ultisol, tiller density in the last assessment at 5764 ADD (390 DAP) was similar when the soil was submitted to CPR and CTA. This difference in tillering between soils may be explained due to the lack of rainfall at the beginning of the experiment in both areas (Figure 1), which can be related to soil water availability. In fact, the Oxisol presents a clayey texture (Table 1) and hence has a porous space between and within aggregates, giving this type of soil a higher water retention. However, the sandy textured Ultisol, although presenting sand particles similar to clay aggregates (Table 1), does not have pores inside, which hinders water retention in the soil and affects the initial growth of plants. 
OXISOL

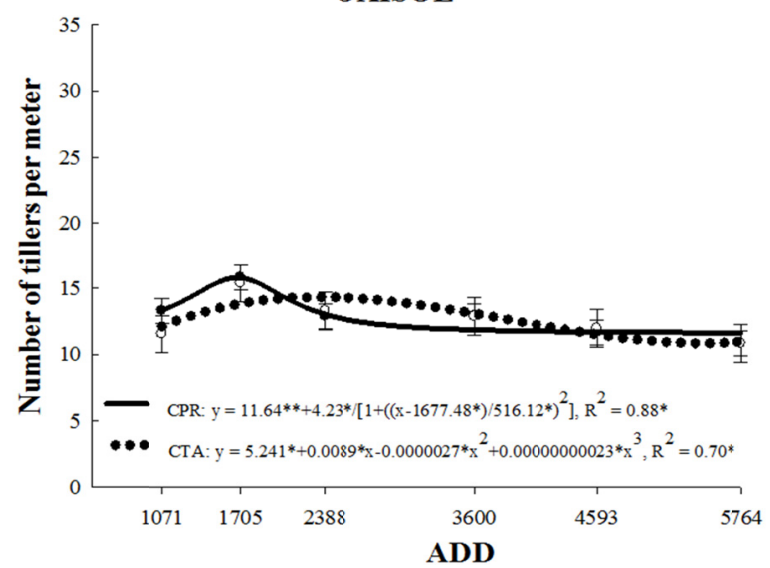

ULTISOL

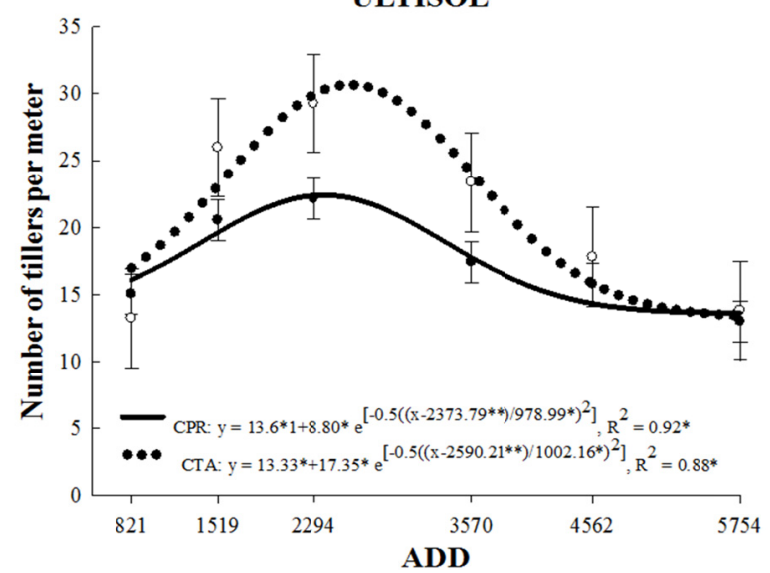

Figure 2. Number of tillers per meter in relation to the sum of accumulated degree-days (ADD, base temperature equal to $10^{\circ} \mathrm{C}$ ) during the sugarcane cycle cultivated in soils with chiseling in the planting row (CPR) and chiseling in total area (CTA). Vertical bars at each point represent the standard error of the mean.

* Significant at $\mathrm{p}<0.05$ and $* *$ significant at $\mathrm{p}<0.01$

At the beginning of sugarcane development, despite the lower rainfall volume and temperature when compared to the end of the crop cycle (Figure 1), an intense tillering was observed since there was water, light, and space for sugarcane root development. During this period, as the first tillers developed and occupied more space in the soil and air their leaves shade those that sprout after and were smaller. Thus, the first tillers were more efficient in the competition mainly by water and light, leading the younger tillers to death before they become adult plants (Santos, 2008).

The number of green leaves per plant increased by 64 and $69 \%$ in the Oxisol submitted to CPR and CTA, respectively, from 1071 ADD (79 DAP) to 1705 ADD (136 DAP) (Figure 3). From there, the number of green leaves varied in relation to the sum of ADD. In the Ultisol, the percentage increase at 1519 ADD (115 DAP) in relation to the first assessment was 73 and $76 \%$ when submitted to CPR and CTA, respectively (Figure 3). Up to 4562 ADD (304 DAP), the number of green leaves per plant remained relatively stable, increasing at the last assessment (Figure 3).
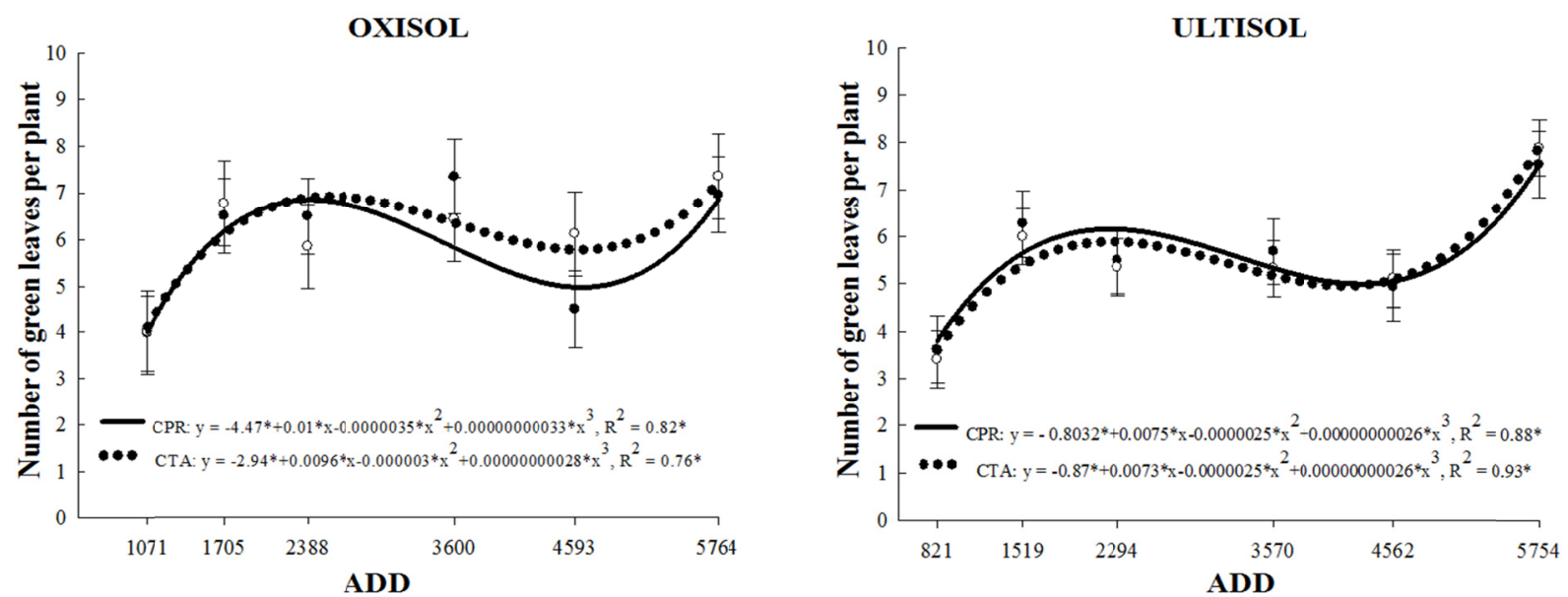

Figure 3. Number of green leaves per plant in relation to the sum of accumulated degree-days (ADD, base temperature equal to $10^{\circ} \mathrm{C}$ ) during the sugarcane cycle cultivated in soils with chiseling in the planting row (CPR) and chiseling in total area (CTA). Vertical bars at each point represent the standard error of the mean.

*Significant at $\mathrm{p}<0.05$

For the studied variables, we observed the moment of growth in which the most expressive accumulations began and the moment in which the accumulation of elements started stabilizing (Table 2). The stabilization of the 
number of dead leaves per plant was not observed when the soils were submitted to the treatments with CPR and CTA (Table 2 and Figure 4).

Table 2. Point of minimum $\left(\mathrm{C}_{\min }\right)$ and maximum curvature $\left(\mathrm{C}_{\max }\right)$ for the number of dead leaves per tiller, leaf area, leaf area index, plant height, and total dry matter in relation to the sum of accumulated degree-days (ADD) during the sugarcane cycle cultivated in soils with chiseling in the planting row (CPR) and chiseling in total area (CTA)

\begin{tabular}{|c|c|c|c|c|}
\hline \multirow{2}{*}{ Variable } & \multicolumn{2}{|c|}{ CPR } & \multicolumn{2}{|c|}{ CTA } \\
\hline & $\mathrm{C}_{\min }$ & $\mathrm{C}_{\max }$ & $\mathrm{C}_{\min }$ & $\mathrm{C}_{\max }$ \\
\hline \multicolumn{5}{|l|}{ Oxisol } \\
\hline Number of dead leaves & 1903 & -1 & 1813 & - \\
\hline Leaf area & 978 & 3300 & 934 & 4465 \\
\hline Leaf area index & 876 & 2861 & 828 & 3637 \\
\hline Plant height & 1897 & - & 2260 & 5438 \\
\hline Total dry matter & 2913 & 5556 & 2999 & - \\
\hline \multicolumn{5}{|l|}{ Ultisol } \\
\hline Number of dead leaves & 2493 & - & 3403 & - \\
\hline Leaf area & - & - & - & - \\
\hline Leaf area index & 662 & 2774 & 870 & 2641 \\
\hline Plant height & 2036 & - & 2170 & - \\
\hline Total dry matter & 2912 & - & 2774 & - \\
\hline
\end{tabular}

Note. ${ }^{1}$ We could not estimate $\mathrm{C}_{\max }$ because there was no stabilization of accumulations.

\section{OXISOL}

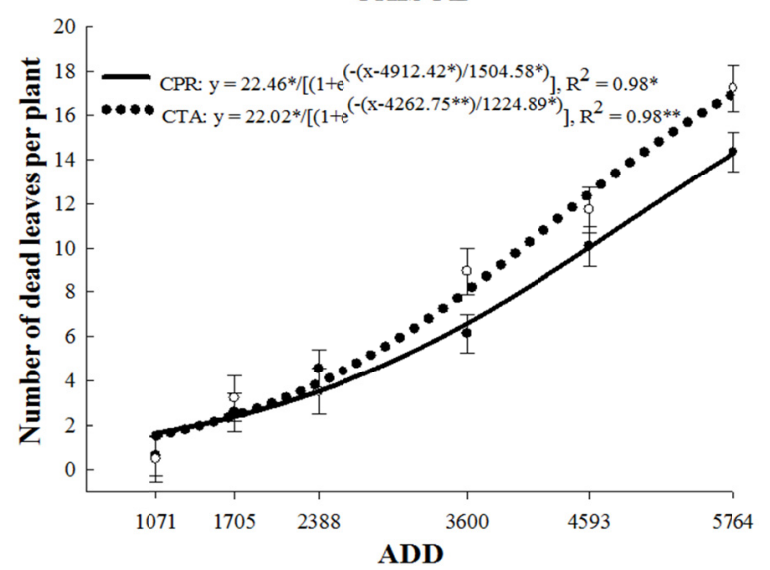

ULTISOL

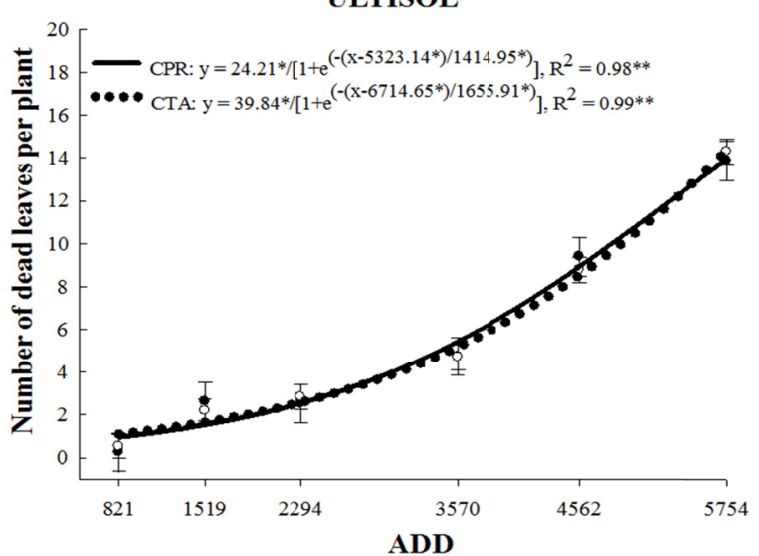

Figure 4. Number of dead leaves per plant in relation to the sum of accumulated degree-days (ADD, base temperature equal to $10^{\circ} \mathrm{C}$ ) during the sugarcane cycle cultivated in soils with chiseling in the planting row (CPR) and chiseling in total area (CTA). Vertical bars at each point represent the standard error of the mean.

*Significant at $\mathrm{p}<0.05$ and $* *$ significant at $\mathrm{p}<0.01$

Regarding the leaf area, the most expressive increases started later and stabilized earlier in the Oxisol when submitted to CPR when compared to CTA. In the Ultisol, the leaf area of sugarcane presented a linear behavior, increasing with the sum of ADD when submitted to CPR and CTA, proving to be an intrinsic characteristic of the used variety (Table 2 and Figure 5). 
OXISOL

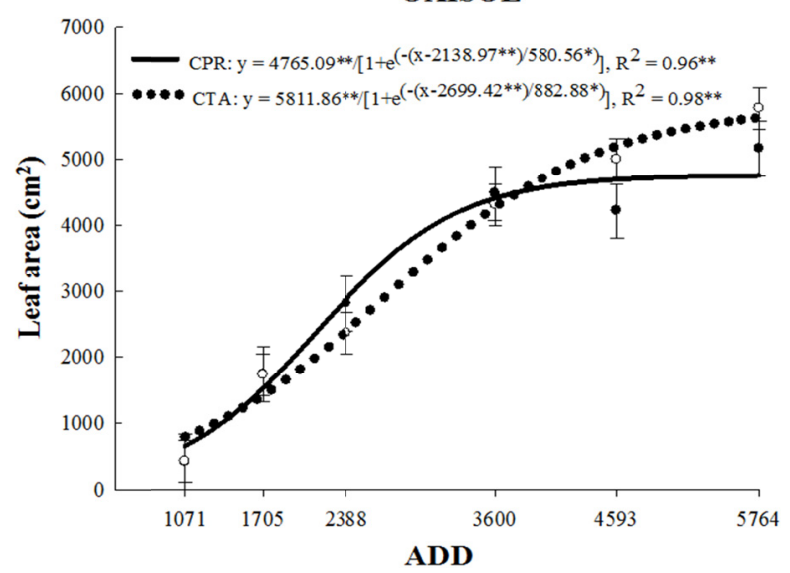

ULTISOL

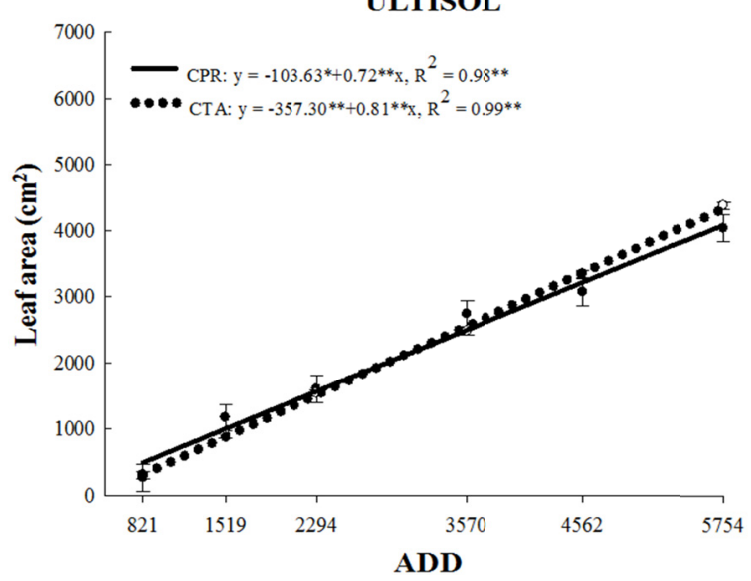

Figure 5. Leaf area $\left(\mathrm{cm}^{2}\right)$ in relation to the sum of accumulated degree-days (ADD, base temperature equal to $10^{\circ} \mathrm{C}$ ) during the sugarcane cycle cultivated in soils with chiseling in the planting row (CPR) and chiseling in total area (CTA). Vertical bars at each point represent the standard error of the mean.

$*$ Significant at $\mathrm{p}<0.05$ and $* *$ significant at $\mathrm{p}<0.01$

The most expressive increments in the leaf area index (LAI) in the Ultisol submitted to CPR started earlier, stabilizing later when compared to the same soil submitted to CTA (Table 2). After stabilization, the plant maintains LAI until the end of the cycle for both soils (Figure 6). The opposite was observed for tillering (Figure 2 ), with the death of tillers until the end of the cycle. By relating these two variables, we can understand the variation in the number of green leaves per plant. It is likely that the plant will be able to regulate the number of green leaves in a way that does not compromise LAI, maintaining the photosynthetic efficiency and accumulation of carbohydrates in the plant.
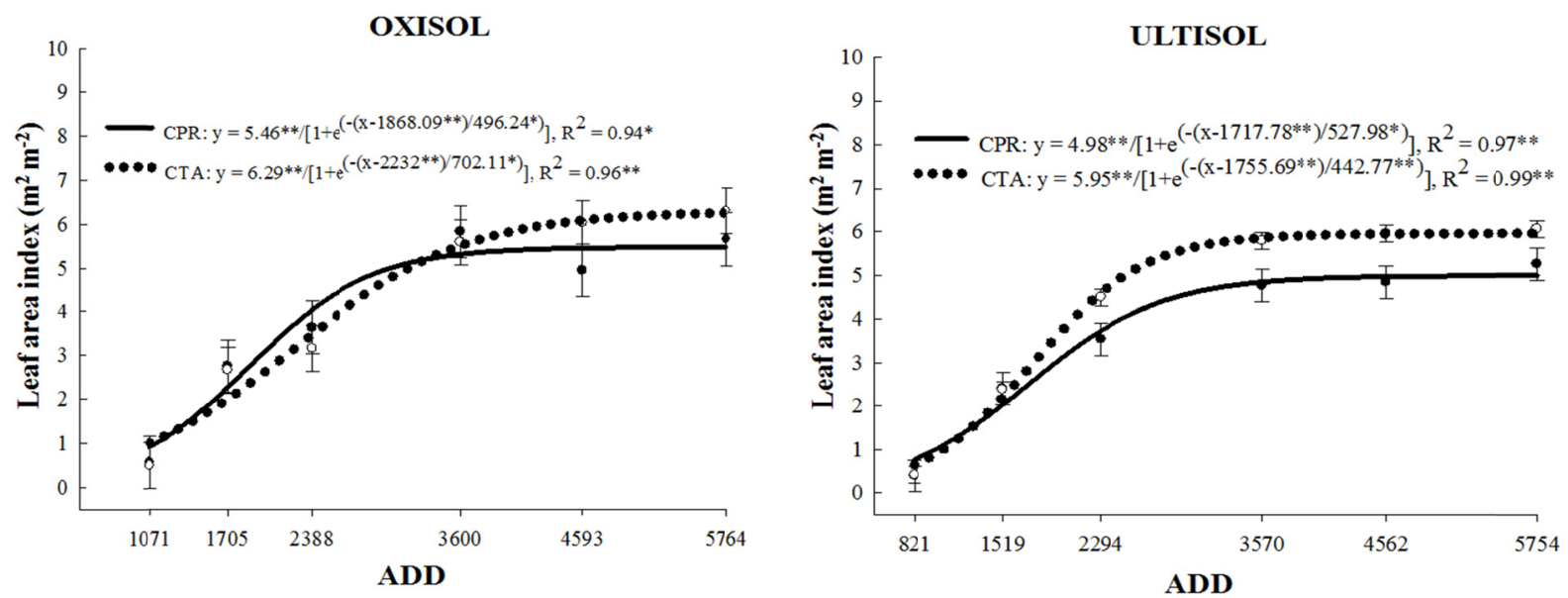

Figure 6. Leaf area index $\left(\mathrm{m}^{2} \mathrm{~m}^{-2}\right)$ in relation to the sum of accumulated degree-days (ADD, base temperature equal to $10^{\circ} \mathrm{C}$ ) during the sugarcane cycle cultivated in soils with chiseling in the planting row (CPR) and chiseling in total area (CTA). Vertical bars at each point represent the standard error of the mean.

*Significant at $\mathrm{p}<0.05$ and $* *$ significant at $\mathrm{p}<0.01$

According to Barbieri (1993), values of LAI above two can lead to tiller death due to competition for light. The values of LAI at 1705 ADD (136 DAP) in the Oxisol were 2.8 and 2.7 when submitted to CPR and CTA, respectively (Figure 6). After this assessment, we observed tiller death (Figure 2), which is in accordance with Barbieri (1993). However, in the Ultisol, tiller death only occurred from 2294 ADD (170 DAP) (Figure 2), with values of LAI for the Ultisol submitted to CPR of 3.54 and for the Ultisol submitted to CTA of 4.49 (Figure 6). Soil type may have contributed to this since the studied areas presented soils with distinct textures, i.e. clayey and sandy textures. In fact, sandy soils show a total porosity lower than that observed in clayey soils since the latter have a large number of internal micropores in their aggregates, giving them a higher water retention when 
compared to sandy soils. This shows that the relationship between LAI and tiller death may vary depending on the cultivated soil, its management, and the used sugarcane variety.

Regarding the variable plant height, the most expressive increments started earlier in both soils submitted to CPR when compared to those submitted to CTA. However, only the Oxisol submitted to CTA showed a stabilization of growth (Table 2 and Figure 7).

OXISOL

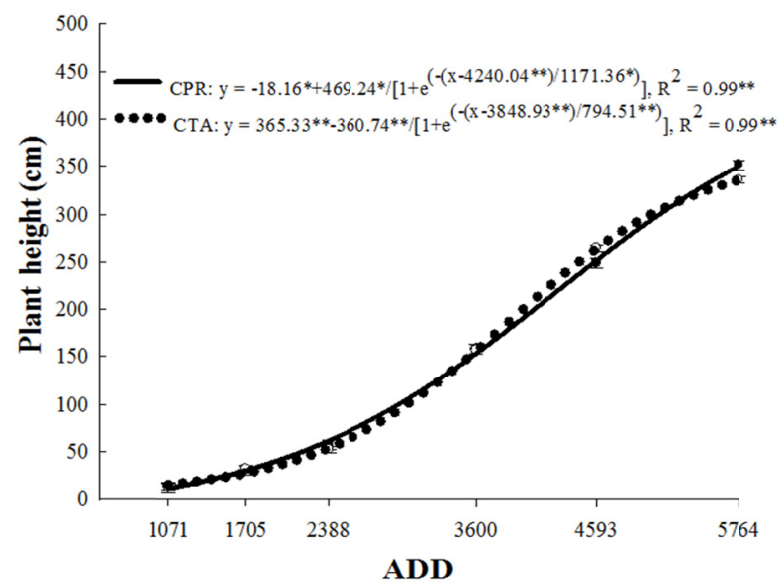

ULTISOL

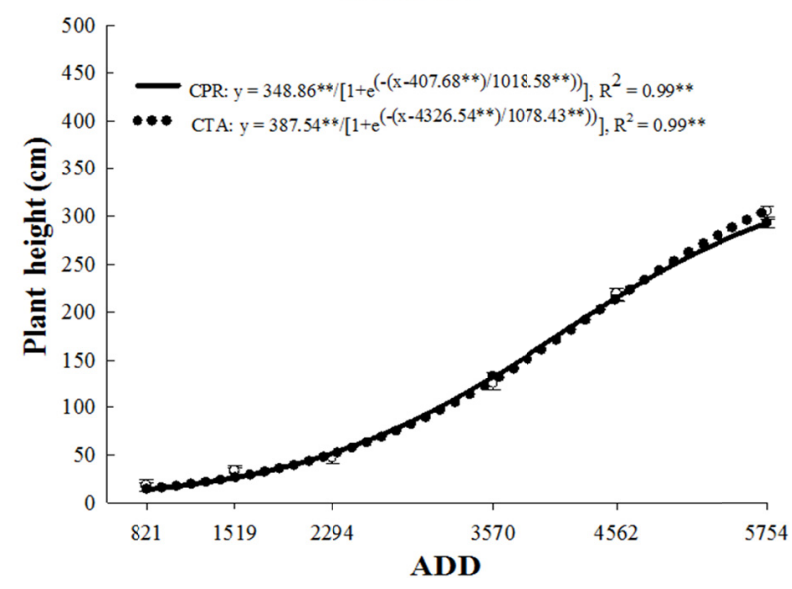

Figure 7. Plant height $(\mathrm{cm})$ in relation to the sum of accumulated degree-days (ADD, base temperature equal to $10^{\circ} \mathrm{C}$ ) during the sugarcane cycle cultivated in soils with chiseling in the planting row (CPR) and chiseling in total area (CTA). Vertical bars at each point represent the standard error of the mean.

*Significant at $\mathrm{p}<0.05$ and ${ }^{* *}$ significant at $\mathrm{p}<0.01$

In the Oxisol, the most expressive increments in total dry matter occurred earlier and the stabilization occurred later in CPR when compared to CTA (Table 2 and Figure 8). In the Ultisol, the most expressive increments occurred later in CPR when compared to CTA, with no stabilization of accumulation when submitted to CTA (Table 2).
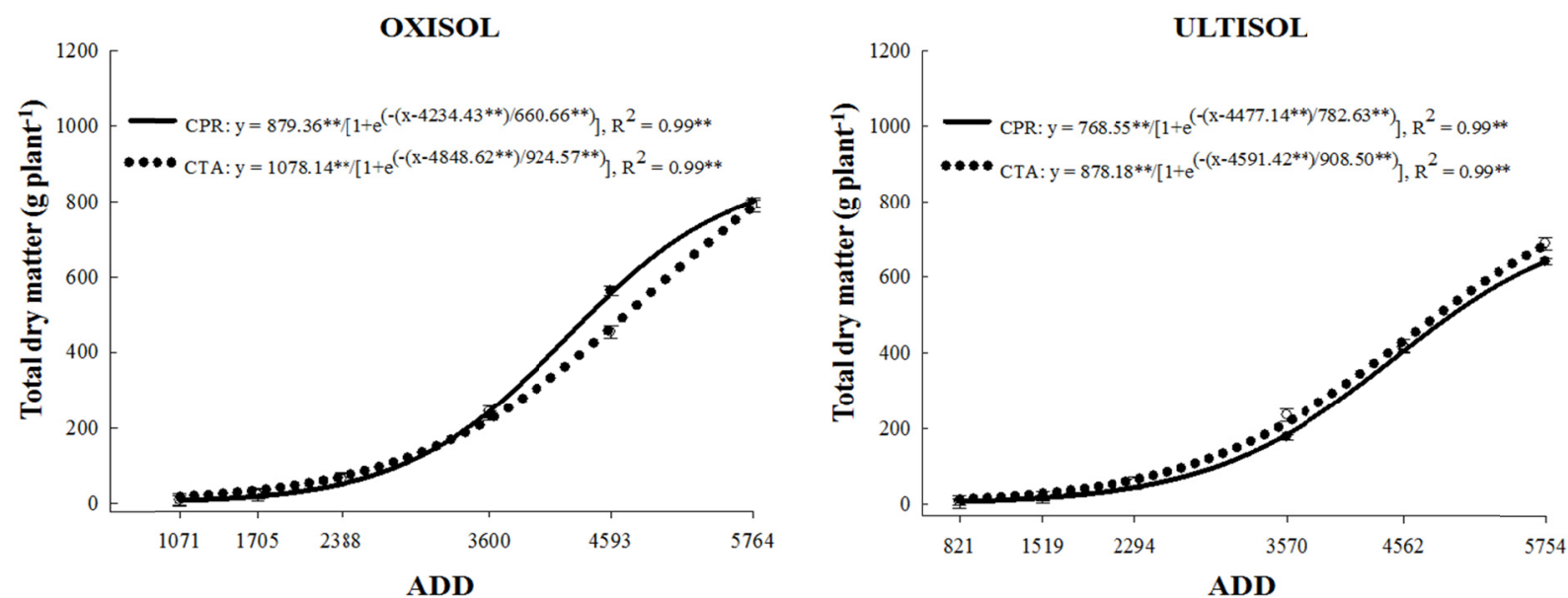

Figure 8. Total dry matter $\left(\mathrm{g} \mathrm{plant} \mathrm{t}^{-1}\right)$ in relation to the sum of accumulated degree-days (ADD, base temperature equal to $10^{\circ} \mathrm{C}$ ) during the sugarcane cycle cultivated in soils with chiseling in the planting row (CPR) and chiseling in total area (CTA). Vertical bars at each point represent the standard error of the mean.

*Significant at $\mathrm{p}<0.01$

The difference observed in sugarcane tillering between treatments submitted to CPR and CTA in the Ultisol did not result in interference in the plant growth in height nor in dry matter accumulation during its cycle. This 
reinforces the hypothesis raised by Terauchi and Matsuoka (2000) that a high tillering in the initial stage may not be a desirable characteristic since it requires a higher energy expenditure for tiller production, which does not necessarily reflect an increased productivity.

Oliveira et al. (2007) observed a negative correlation between tillering and total dry matter production of sugarcane. Ramesh and Mahadevaswamy (2000) reported that the sugarcane with a lower tiller density tends to present a higher height. In the Ultisol, the lower tillering observed when submitted to CPR (Figure 2) did not reflect in a higher plant height. This is probably because the most significant increases in plant height started close to the assessment in which it reached the maximum tillering.

The maximum values obtained for LAI by the equations varied between 5 and 6.4 (Figure 6). Machado et al. (1985) pointed out that an LAI of 4 is enough for plants to intercept $95 \%$ of incident solar radiation. An LAI between 5 and 6 seems to be ideal since the highest increases in stalk dry matter start after LAI stabilization, i.e. in the first stage of growth, there was an intense tillering and a marked increase in the number of green leaves per plant. Then, intense increases in plant height were observed until LAI stabilization was reached and then the beginning of an intense dry matter accumulation in the stalks.

No difference $(\mathrm{p}<0.05)$ was observed for stalk productivity of the sugarcane cultivated in soils under CPR and CTA. In the Oxisol, stalk productivity was $104 \mathrm{t} \mathrm{ha}^{-1}$ in CPR and $101 \mathrm{t} \mathrm{ha}^{-1}$ in CTA. In the Ultisol, stalk productivity was 109 and $111 \mathrm{t} \mathrm{ha}^{-1}$ when submitted to CPR and CTA, respectively (Figure 9). This occurred because chiseling was carried out in the planting row in both treatments, i.e. in the place where the sugarcane was developed. Thus, soils submitted to CPR and CTA provided favorable conditions for plant growth.
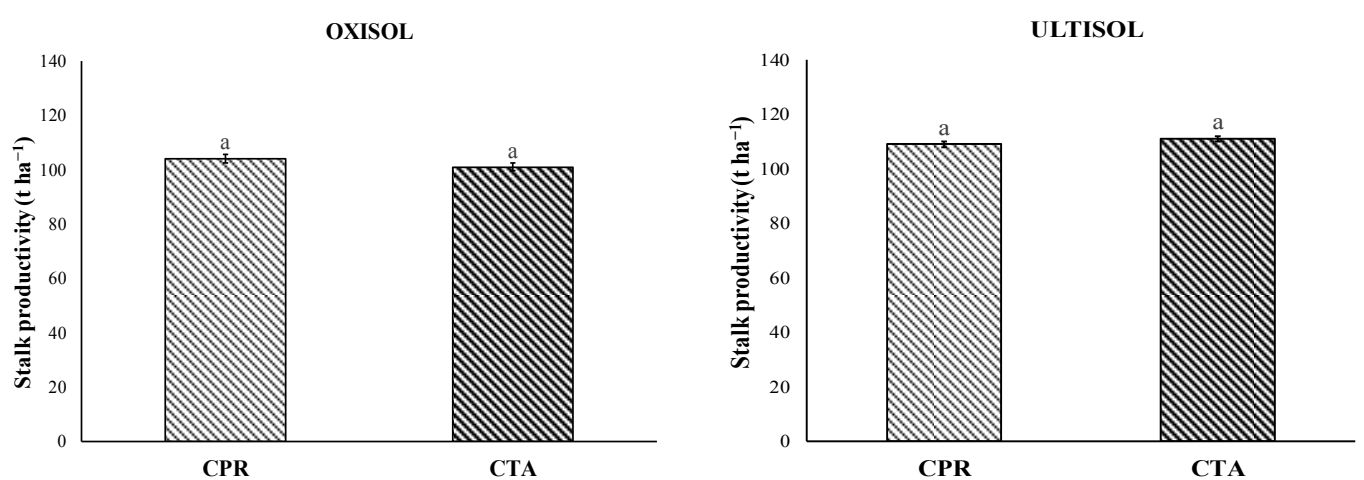

Figure 9. Stalk productivity $\left(\mathrm{t} \mathrm{ha}^{-1}\right)$ of sugarcane cultivated in soils with chiseling in the planting row $(\mathrm{CPR})$ and chiseling in total area (CTA). Vertical bars at each point represent the standard error of the mean. Equal letters indicate no difference by the Tukey's test $(\mathrm{p}<0.05)$

Stalk productivity obtained in both areas were close to that described by the Sugarcane Technology Center (CTC). According to CTC (2018), the varieties used in this experiment, considering the edaphoclimatic variations of each production environment, have the potential to reach an average productivity of $110 \mathrm{tha}^{-1}$ for CTC 14 and $116 \mathrm{tha}^{-1}$ for CTC 4 in the first cut.

In this sense, this study has its importance since the soils submitted to CPR did not compromise crop production. This soil tillage operation allowed a lower cost for sugarcane field implantation, also reducing the emission of pollutants due to the shortest time of use of agricultural machinery. In addition, according to Souza et al. (2017), a soil tillage with $\mathrm{CPR}$ also results in a lower $\mathrm{CO}_{2}$ emission to the atmosphere when compared to CTA.

\section{Conclusion}

Soil tillage with chiseling in the planting row and in total area provided favorable conditions for growth and productivity of sugarcane under an Oxisol and Ultisol.

Soil tillage with chiseling in total area can be replaced by chiseling in the planting row since growth and productivity of sugarcane stalks were similar regardless of the location of the chiseling operation. Thus, the adoption of a soil tillage with chiseling in the planting row leads to less soil mobilization and reduction of production costs for farmers in the initial phase of planting. 


\section{References}

Barbieri, V. (1993). Condicionamento climático da produtividade potencial da cana-de-açúcar (Saccharum spp.): Um modelo matemático-fisiológico de estimativa (Doctoral thesis, Universidade de São Paulo, Piracicaba, Brazil).

Cherubin, M. R., Franco, A. L. C., Guimarães, R. M. L., Tormena, C. A., Cerri, C. E. P., Karlen, D. L., \& Cerri, C. C. (2017). Assessing soil structural quality under Brazilian sugarcane expansion areas using Visual Evaluation of Soil Structure (VESS). Soil and Tillage Research, 173, 64-74. https://doi.org/10.1016/j.still. 2016.05.004

Claessen, M. E. C. (1997). Manual de métodos de análise de solo. Rio de Janeiro, RJ: Centro Nacional de Pesquisa de Solos.

CONAB (Companhia Nacional de Abastecimento). (2017). Acompanhamento da safra brasileira: Cana-de-açúcar. Retrieved from https://www.conab.gov.br/OlalaCMS/uploads/arquivos/170420140431bole tim_cana_portugues $1 \% \mathrm{C} 2 \% \mathrm{BA} \% 20$ levantamento, $17-18$

CTC (Centro de Tecnologia Canavieira). (2018). Análise comercial das variedades CTC 4 e CTC 14. Retrieved from https://variedadesctc.com.br/produtos/ctc-4

Hermann, E. R., \& Câmara, G. M. S. (1999). Um método simples para estimar a área foliar de cana-de-açúcar. Revista da STAB, 17(5), 32-34.

Machado, E. C., Pereira, A. R., Camargo, M. B. P., \& Fahl, J. I. (1985). Relações radiométricas de uma cultura de cana-de-açúcar. Bragantia, 44(1), 229-238. https://doi.org/10.1590/S0006-87051985000100021

Marafon, A. C. (2012). Análise quantitativa de crescimento em cana-de-açúcar: Uma introdução ao procedimento prático (Embrapa Tabuleiros Costeiros, Documentos, 168). Aracaju, SR: Embrapa Tabuleiros Costeiros.

Marin, F. R. (2017). Árvore do Conhecimento: Cana-de-açúcar. Solos do Brasil e a cana-de-açúcar. Agência Embrapa de Informação Tecnológica, Brasília, DF: Embrapa. Retrieved from http://www.agencia.cnptia. embrapa.br/gestor/cana-de-acucar/arvore/CONTAG01_18_3112006152934.html

Mialhe, L. G. (1974). Manual de mecanização agrícola. São Paulo, SP: Ceres.

Nassif, D. S. P., Marin, F. R., \& Costa, L. G. (2013). Padrões mínimos para coleta de dados experimentais para estudos sobre crescimento e desenvolvimento da cultura da cana-de-açúcar (Embrapa Informática Agropecuária, Documentos, 127). Campinas, SP: Embrapa Informática Agropecuária.

Oliveira, P. R., Centurion, J. F., Centurion, M. A. P. C., Rossetti, K. V., Ferraudo, A. S., Franco, H. B. J., Pereira, F. S., \& Bárbaro Júnior, L. S. (2013). Qualidade estrutural de um latossolo vermelho submetido à compactação. Revista Brasileira de Ciência do Solo, 37(3), 604-612. https://doi.org/10.1590/S0100-068320 13000300006

Perecin, D., Ferraudo, G. M., Azania, C. A. M., \& Schiavetto, A. R. (2015). Statistical analysis for correlated paired-plot designs. American Journal of Experimental Agriculture, 9(6), 1-7. https://doi.org/10.9734/AJEA

Prado, H. (2016). Pedologia fácil: Aplicações em solos tropicais (5th ed.). Revisada e atualizada. Piracicaba, SP: Esalq/USP.

Raij, B. V., Andrade, J. C., Cantarella, H., \& Quaggio, J. A. (2001). Análise química para avaliação da fertilidade de solos tropicais. Campinas, SP: Instituto Agronômico.

Raij, B. V., Cantarella, H., Quaggio, J. A., \& Furlani, A. M. C. (1997), Recomendação de adubação e calagem para o Estado de São Paulo (Boletim Técnico IAC, 100). Campinas, SP: Instituto Agronômico.

Ramesh, P., \& Mahadevaswamy, M. (2000). Effect of formative phase drought on different classes of shoots, shoot mortality, cane attributes, yield and quality of four sugarcane cultivars. Journal of Agronomy and Crop Science, 185(4), 249-258. https://doi.org/10.1046/j.1439-037x.2000.00399.x

Santos, A. C. A. (2008). Avaliação de genótipos de cana-de-açúcar para as condições edafoclimáticas de Aparecida do Taboado-MS (Masters Dissertation, Universidade Estadual Paulista, Ilha Solteira, Brazil).

Smit, M. A., \& Singels, A. (2006). The response of sugarcane canopy development to water stress. Field Crops Research, 98(1-2), 91-97. https://doi.org/10.1016/j.fcr.2005.12.009

Souza, L. C., Fernandes, C., Nogueira, D. C. S., Moitinho, M. R., Bicalho, E. S., \& La Scala, N. (2017). Can partial cultivation of only the sugarcane row reduce carbon dioxide emissions in an oxisol and ultisol? 
Agronomy Journal, 109(3), 1113-1121. https://doi.org/10.2134/agronj 2016.10.0565

Terauchi, T., \& Matsuoka, M. (2000). Ideal characteristics for the early growth of sugarcane. Japanese Journal of Crop Science, 69, 286-292. https://doi.org/10.1626/jcs.69.286

Venegas, J. G., Harris, R. S., \& Simon, B. A. (1998). A comprehensive equation for the pulmonary pressure-volume curve. Journal of Applied Physiology, 84(1), 389-395. https://doi.org/10.1152/jappl.1998. 84.1.389

Yeomans, J. C., \& Bremner, J. M. (1988). A rapid and precise method for routine determination of organic carbon in soil. Communication in Soil Science and Plant Analysis, 19(13), 1467-1476. https://doi.org/ $10.1080 / 00103628809368027$

\section{Copyrights}

Copyright for this article is retained by the author(s), with first publication rights granted to the journal.

This is an open-access article distributed under the terms and conditions of the Creative Commons Attribution license (http://creativecommons.org/licenses/by/4.0/). 